\title{
Pembelajaran Bahasa Inggris Berbasis Lagu dan Media Audio Visual
}

\author{
Ratnawati ${ }^{*}$, Lusy Angraeni ${ }^{2}$ \\ 1,2, Akademi Bahasa Asing UMI Makassar \\ ${ }^{1}$ ratnawati.ratnawati@umi.ac.id, ${ }^{2}$ lusy.angraeni@umi.ac.id
}

\begin{abstract}
Abstrak
Pembelajaran Bahasa Inggris berbasis lagu dan media audio-visual sangat cocok diimplementasikan bagi siswa khususnya di tingkat dasar. Lagu menjadi sumber belajar yang baik untuk pembelajaran bahasa Inggris dengan didukung media audiovisual karena sangat mendukung proses belajar siswa dalam meningkatkan kemampuannya dalam melafalkan, menghafalkan kosakata dan ungkapan bahasa Inggris yang sederhana. Penerapan lagu dan media audio-visual sesuai dengan kebutuhan anak dalam proses belajar. Selama kegiatan pembelajaran bahasa Inggris berlangsung, siswa diberi stimulasi dengan memperdengarkan lagu yang dapat dilihat dan didengar langsung dan sesuai dengan target yang ingin dicapai dari pengajaran ini yaitu siswa partisipasi aktif mampu melafalkan, menghafalkan kosa kata dan ungkapan bahasa Inggris yang sederhana. IbM pengabdian yang dilakukan benar-benar merupakan kegiatan yang bersinergi secara positif dengan masyarakat khususnya siswa TPA Jannatul Firdaus. Hasil kegiatan pengabdian selama 3 (tiga) bulan menunjukkan kemampuan siswa yang mengalami peningkatan yang cukup baik dalam memahami bahasa Inggris. Hal ini dapat dilihat melalui partisipasi siswa sejak awal hingga akhir kegiatan. Para siswa lebih bersemangat dan percaya diri dalam mengucapkan kata-kata sederhana dalam Bahasa Inggris.
\end{abstract}

Kata Kunci: lagu, media audio visual, Bahasa Inggris, TPA Jannatul Firdaus

\section{Pendahuluan}

Bahasa Inggris menjadi salah satu bahasa asing yang dijadikan sebagai pengantar komunikasi internasional. Bahasa asing telah menjadi salah satu media komunikasi yang vital di era ini termasuk di Indonesia. Hal ini sejalan dengan usaha pemerintah untuk menyiapkan pebelajar yang handal dan berkualitas, sehingga nantinya mampu bersaing di tingkat nasional maupun internasional. Namun, bahasa Inggris masih menjadi momok bagi para siswa khususnya dalam melafalkan dan menghafalkan kosakata. Oleh karena itu, pembelajaran bahasa Inggris untuk anak-anak berbeda dengan pembelajaran untuk orang dewasa. Anak-anak pada umumnya memiliki rasa ingin tahu yang besar, senang bermain dan memiliki konsentrasi yang singkat.

Pembelajaran Bahasa Inggris di SD/MI bertujuan untuk mengembangkan kompetensi berkomunikasi dalam bentuk lisan secara terbatas untuk mengiringi tindakan (language accompanying action) dalam konteks sekolah dan memiliki kesadaran tentang hakikat dan pentingnya bahasa Inggris untuk meningkatkan daya saing bangsa dalam masyarakat global. Maka pembelajaran bahasa Inggris harus lebih ditekankan pada 
pembelajaran mendengarkan (listening) dan berbicara (speaking) yang tetap didukung dengan komponen kebahasaan seperti kosakata, gramatika, pelafalan, dan intonasi, juga inklusif diajarkan. Dan ini dapat dilakukan dengan memanfaatkan lagu-lagu berbahasa Inggris.

Pembelajaran bahasa Inggris berbasis lagu sangat relevan disandingkan dengan alat bantu media khususnya audio-visual dan bisa menjadi sumber bahasa yang otentik bagi siswa. Hampir tak ada batas waktu dalam menggunakan lagu untuk mengajar bahasa Inggris, siswa bisa menggunakan lagu sebagai input bahasa kapan pun mereka mau, baik di dalam kelas maupun di luar kelas. Tujuan pembelajaran bahasa Inggris berbasis lagu dan media audio-visual ini diharapkan dapat mengembangkan kemampuan siswa dalam mempelajari bahasa Inggris terkhusus pada pelafalan dan kosakata.

Taman Pendidikan Alqur'an (TPA) Jannatul Firdaus merupakan lokasi pengabdian yang dipilih dengan pertimbangan bahwa TPA yang membina siswa dari tingkat TK dan SD ini hanya fokus pada pembelajaran mengenai baca tulis Al-qur'an. Mereka tidak dibekali ilmu pengetahuan lain kecuali yang mereka dapatkan dari bangku sekolah. TPA Jannatul Firdaus terletak di kota Makassar, berjarak sekitar $4.5 \mathrm{~km}$ dari lokasi Perguruan Tinggi Universitas Muslim Indonesia, yang tidak jauh dari pusat kota dan dapat diakses dengan mudah, sehingga memungkinkan penerapan pembelajaran bahasa Inggris lebih mudah dilakukan. Terlebih lagi, hasil wawancara informal dengan ketua RT, kepala sekolah dan siswa TPA Jannatul Firdaus, tim pengabdi mendapat informasi bahwa siswa di TPA ini belum pernah mengikuti kegiatan semacam ini, sehingga mereka sangat antusias menunggu kegiatan ini dilaksanakan.

Dari semua temuan diatas, maka tim pengabdi kegiatan IbM merasa berkepentingan untuk membantu para siswa agar dapat meningkatkan kemampuan bahasanya melalui lagu dan media audio-visual. Melalui kegiatan tersebut para siswa akan diperkenalkan dengan pelafalan dan kosakata sesuai dengan tingkatannya.

\section{Metode Pelaksanaan}

Kegiatan pelaksanaan pengabdian sesuai dengan yang ada di lapangan meliputi kegiatan pelaksanaan pembelajaran Bahasa Inggris bagi siswa TPA Jannatul Firdaus berlokasi di Jl. Tinumbu Pannampu Blok D yang dimulai pada hari Rabu tanggal 21 November 2018 pada pukul 13.30 wita dan diikuti sebanyak 20 siswa serta tim pelaksana pengabdian yang terdiri atas dosen dan mahasiswa. Kegiatan tersebut berlangsung hingga tanggal 20 Januari 2019.

Kegiatan ini berlangsung selama tiga (3) bulan dan dilaksanakan selama 90 menit dengan frekuensi pertemuan dua hingga tiga kali pertemuan. Pada pertemuan pertama yaitu pada Rabu tanggal 21 November 2018, tim pelaksana pengabdian memberikan materi Introduction: Greetings (perkenalan), pada tanggal 23 November 2018 materi yang disajikan adalah alphabet (abjad), tanggal 28 November 2018 dengan materi Number (angka), 05 Desember 2018 dengan materi Days, Month and Year (hari,bulan dan tahun), tanggal 12 Desember 2018 dengan materi Colour (warna), 19 Desember 2018 dengan materi Fruits and Vegetables (buah dan sayuran), 05 Januari 2019 dengan materi Parts of Body (anggota tubuh), 13 Januari 2019 dengan materi shape (bentuk), 19 Januari 2019 dengan materi Family Tree (keluarga), dan materi yang diberikan pada tanggal 20 Januari 
2019 yang merupakan pertemuan terakhir dari pelaksanaan pembelajaran adalah Noun (benda).

\section{Mitra Kegiatan}

TPA Jannatul Firdaus merupakan mitra dalam kegiatan pengabdian kepada masyarakat (IbM) yang terletak di kota Makassar yang berjarak $4.5 \mathrm{KM}$ dari lokasi Perguruan Tinggi Akademi Bahasa Asing UMI Makassar dan diikuti oleh 20 orang siswa.

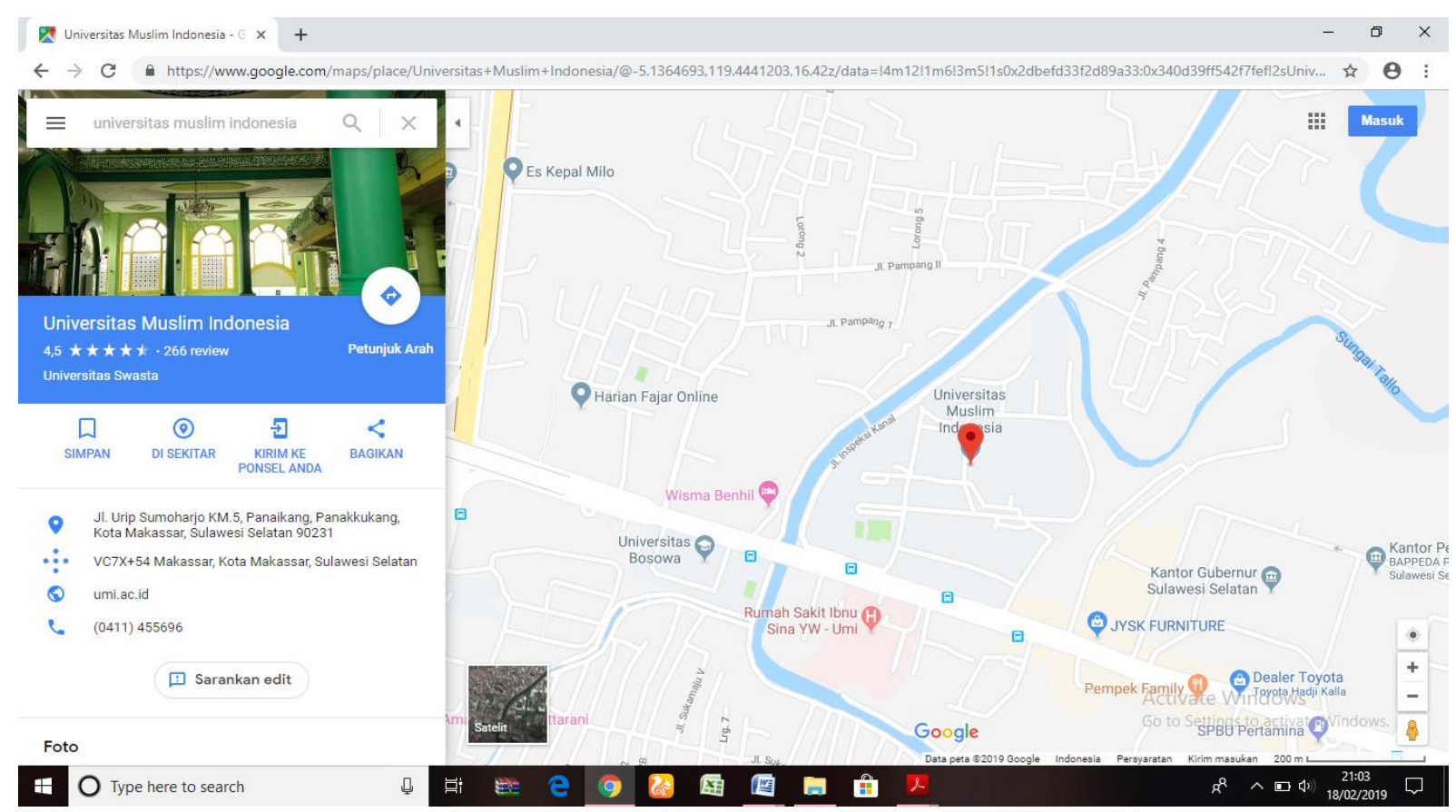

Gambar 1. Lokasi kegiatan

\section{Hasil dan Pembahasan}

Pembelajaran Bahasa Inggris dalam kegiatan pengabdian ini meningkatkan kepercayaan diri para siswa dalam mengucapkan kata-kata sederhana dalam bahasa Inggris. Hal ini ditunjukkan dengan semangat dan antusias siswa tergambar dengan jelas selama mengikuti proses pembelajaran bahasa Inggris.

\section{Pertemuan Pertama}

Pertemuan pertama dilaksanakan pada hari Rabu, 21 November 2018 di Masjid Jannatul Firdaus Pukul 13.30-15.00 dan diikuti oleh 20 siswa TPA Jannatul Firdaus. Tim pengabdi memberikan materi Introduction: Greetings. Di awal pertemuan, tim pengabdi memperlihatkan dan memutarkan lagu Introduction: Greetings lalu diikuti dengan perkenalan oleh siswa TPA Jannatul Firdaus.

Siswa merasa senang karena ini merupakan pengalaman baru bagi mereka belajar bahasa Inggris selain dari yang mereka dapatkan di sekolah.

\section{Pertemuan Kedua}

Pada Pertemuan kedua yang dilaksanakan pada hari Jumat, 23 November Pukul 13.30 - 15.00, pelaksanaan kegiatan ini difokuskan pada materi abjad (Alphabet) untuk diperkenalkan pada siswa. Kegiatan ini diawali dengan menyajikan lagu abjad dengan 
menggunakan media audio-visual agar menambah daya tarik dan konsentrasi siswa dalam belajar. Ini dilakukan sesuai dengan kebutuhan siswa khususnya siswa TK dan Sekolah Dasar.

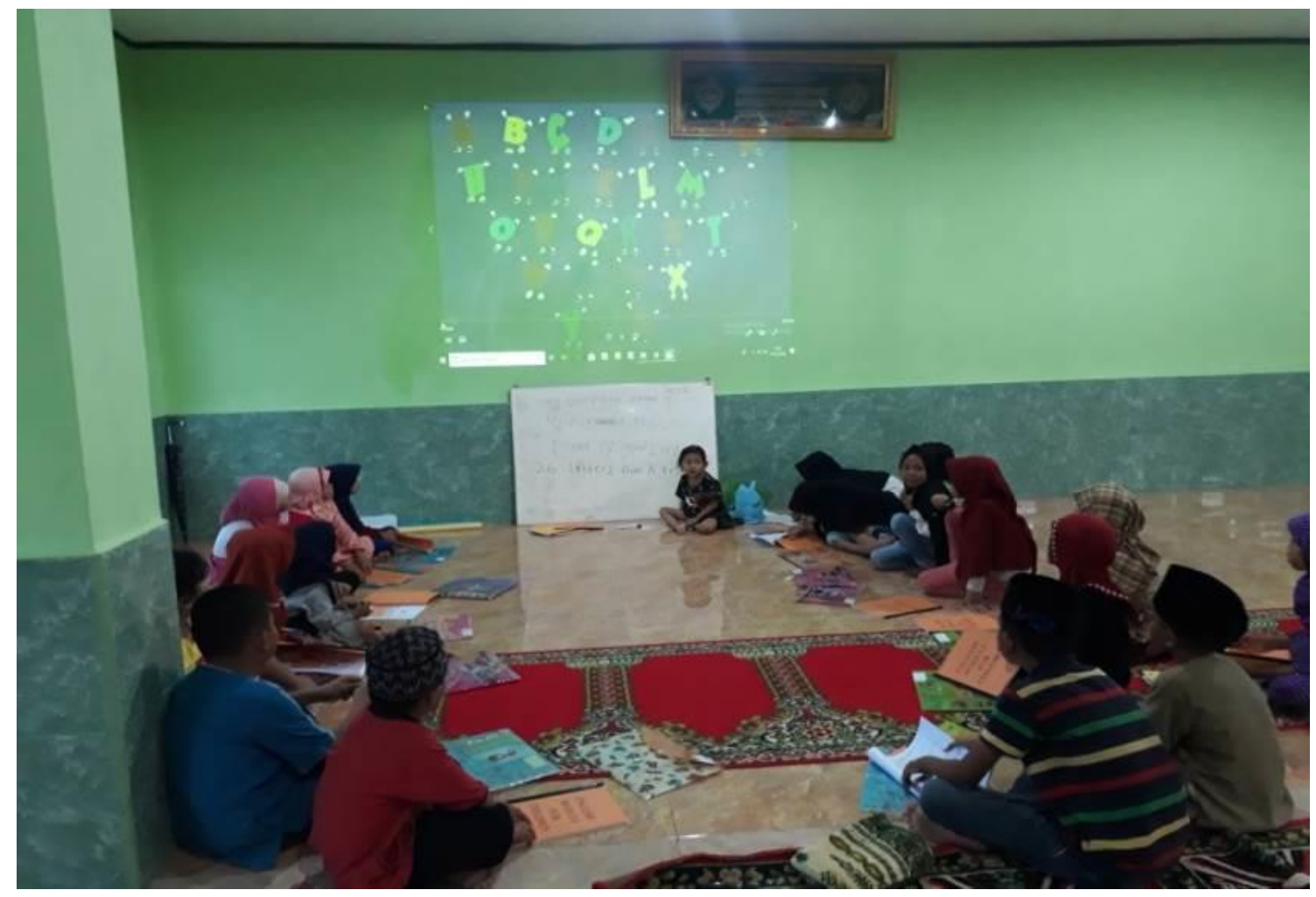

Gambar 2. Materi pembelajaran Huruf (alphabet)

\section{Pertemuan Ketiga}

Pelatihan ketiga dilaksanakan pada hari Rabu, 28 November 2018. Pembelajaran diawali dengan mengulang materi dan lagu yang telah diberikan, kemudian dilanjutkan dengan materi angka (Number). Dalam setiap penyajian materi selalu dibarengi dengan menampilkan lagu yang dapat dilihat dan didengar langsung oleh siswa. Dengan menggunakan media seperti ini, siswa secara langsung mengikuti apa yang mereka lihat dan dengar dan secara otomatis akan terbawa dalam kesehariannya.

Kegiatan pembelajaran bahasa Inggris hari ini mengalami kemajuan dilihat dari partisipasi siswa selama proses belajar. Mereka sudah mulai memberanikan diri untuk mengajukan diri menjawab pertanyaan yang diberikan.

\section{Pertemuan Keempat}

Pertemuan keempat dilaksanakan pada hari Rabu, 05 Desember 2018. Pelatihan diawali dengan mengulang semua lagu pada pertemuan-pertemuan sebelumnya. Kemudian dilanjutkan dengan materi baru yaitu lagu Days, Month and Year yang berkenaan dengan pengenalan hari. Tim pengabdi memperdengarkan lagu kepada siswa dan diminta menyanyikan lagu tersebut bersama-sama.

Selanjutnya tim meminta kesediaan siswa untuk menyanyikan lagu tersebut. Ini bertujuan agar siswa mampu membangun kepercayaan dirinya secara personal sehingga mereka tidak malu untuk berpartisipasi dalam setiap kegiatan. Lebih lanjut, tim memberikan permainan yang bertemakan Cross and Match dimana siswa harus bekerja 


\section{Madaniya \\ ISSN 2721-4834}

secara individu. Kemudian tim menjelaskan cara memainkan game tersebut yaitu dengan mencocokkan kata yang berbahasa Indonesia dengan versi bahasa Inggrisnya kemudian silangkan. Siswa yang paling cepat menyelesaikan permainan maka dialah pemenangnya.

\section{Pertemuan Kelima dan Keenam}

Pada hari Rabu, 12 Desember 2018, materi yang diberikan yaitu warna (colour). Tim pelaksana memulai pembelajaran dengan memberikan pertanyaan seputar warna kemudian tim memutar sebuah video lagu yang memiliki warna yang berbeda-beda. Materi yang diberikan dikombinasikan dengan materi lain sehingga secara otomatis materi pada pertemuan sebelumnya selalu mengalami pengulangan. Itu bertujuan agar siswa dapat mengingat kembali materi yang telah diajarkan. Berdasarkan hasil pengamatan dan partisipasi siswa selama proses belajar, dapat disimpulkan bahwa terdapat 14 (empat belas) siswa yang memiliki kemampuan cukup baik dalam memahami materi, 5 (lima) siswa yang memiliki kemampuan rata-rata dan 1 (satu) siswa yang memiliki kemampuan masih rendah.

Pada hari Rabu, 19 Desember 2018, materi yang diberikan yaitu buah dan sayuran (Fruits and Vegetables). Tim pelaksana membuka pembelajaran dengan memperlihatkan sebuah gambar yang didalamnya terdapat banyak buah. Tim memberi pertanyaan berupa "What fruit is this?", "Do you have fruits?", "Do you like banana?". Setelah mendapat respon dari siswa, tim pelaksana memutarkan lagu yang membahas mengenai lagu yang membuat para siswa ikut bernyanyi. Kegiatan selanjutnya, tim menyediakan kartu yang bergambar dan harus mereka tebak buah dan sayuran apa yang tertera di kartu tersebut. Tim pelaksana membagi 5 (lima) kelompok dalam permainan ini. Jika mereka bisa menebak dan menulis nama buah dan sayuran dengan benar maka kelompok mereka yang menjadi pemenang.

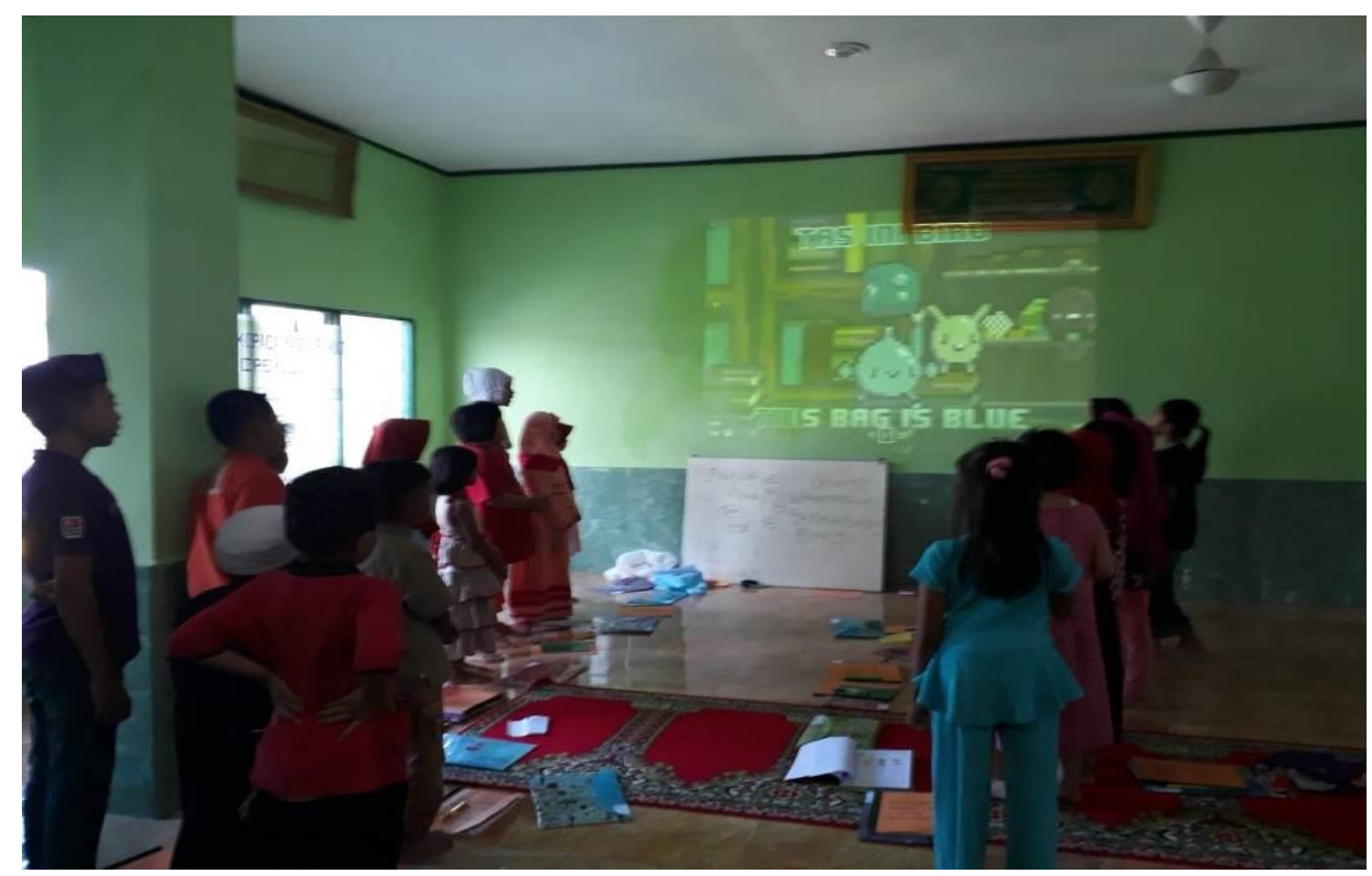

Gambar 3. Materi pembelajaran Warna (alphabet) 


\section{Pertemuan Ketujuh, Kedelapan, Kesembilan dan Kesepuluh}

Pertemuan selanjutnya dilaksanakan pada hari Sabtu, 05 Januari 2019 dengan materi "Parts of Body". Pertemuan kali ini menggunakan Demonstran Method yaitu mendemonstrasikan atau mengikuti instruksi dari tim pelaksana seperti hands up, palms together, elbow together, knee together. Akan tetapi sebelumnya didahului dengan aktifitas bernyanyi untuk memperkenalkan bagian-bagian tubuh dalam bahasa Inggris kepada siswa. Pemutaran lagu dilakukan secara berulang-ulang agar siswa tidak hanya mampu menyanyikan lagu tersebut tetapi juga mempelajari pelafalannya dengan benar. Untuk membuat siswa lebih bersemangat, tim pelaksana memberikan permainan berupa Identifying parts of body, selanjutnya menginstruksikan kepada siswa untuk berdiri kemudian membaginya kedalam 5 (lima) kelompok. Satu dari anggota kelompok bertugas sebagai patung, dan yang lain bertugas untuk menulis dan menempelkan kertas pada bagian anggota tubuh si peraga/ patung dengan cepat dan tepat.

Pertemuan selanjutnya dilaksanakan pada hari Ahad, 13 Januari 2019 dengan materi Shape (bentuk). Tim pelaksana menyediakan beberapa alat bantu berbentuk lingkaran, kotak, segitiga, bintang dan juga bentuk hati untuk ditunjukkan kepada siswa. ini dilakukan untuk mengetahui pemahaman siswa sebelum menampilkan lagu shape. Belajar dengan bernyanyi sangat menarik perhatian siswa dan itu membuat mereka lebih mudah memahami materi yang diberikan karena disajikan secara autentik.

Pertemuan yang kesembilan dilaksanakan pada hari Sabtu, 19 Januari 2019 dengan materi Family Tree. Sebelum memutarkan lagu, tim pelaksana menampilkan gambar sebuah keluarga yang terdiri dari ayah, ibu, kakek, nenek, kakak dan adik. Tim mengajukan pertanyaan berupa "Who are they?" "Is she a mother?". Setelah penyampaian materi diselingi dengan permainan yang relevan dengan materi yang diberikan salah satunya adalah pair work. Kemampuan yang diperoleh dari peserta didik yakni: siswa mampu menguasai dan memahami istilah anggota keluarga serta membuat kalimat sederhana yang berkaitan dengan family member dalam bahasa Inggris.

Pembelajaran Bahasa Inggris yang terakhir dilaksanakan oleh tim pelaksana pengabdian pada hari Ahad 20 Januari 2019. Topik yang diberikan yaitu Noun dengan menggunakan metode tanya jawab. Tim pelaksana menunjuk beberapa benda yang ada disekitar seperti buku, pulpen dan lain-lain kemudian memberikan pertanyaan kepada siswa 'what is this?', 'whose thing is this?. Setelah itu, tim memutarkan lagu tentang bendabenda yang umum digunakan. Bentuk kemampuan yang diperoleh oleh siswa yaitu siswa dapat memahami bentuk pertanyaan dan penggunaan kata 'this' serta kepemilikan dengan tepat ' $m y$ '. 


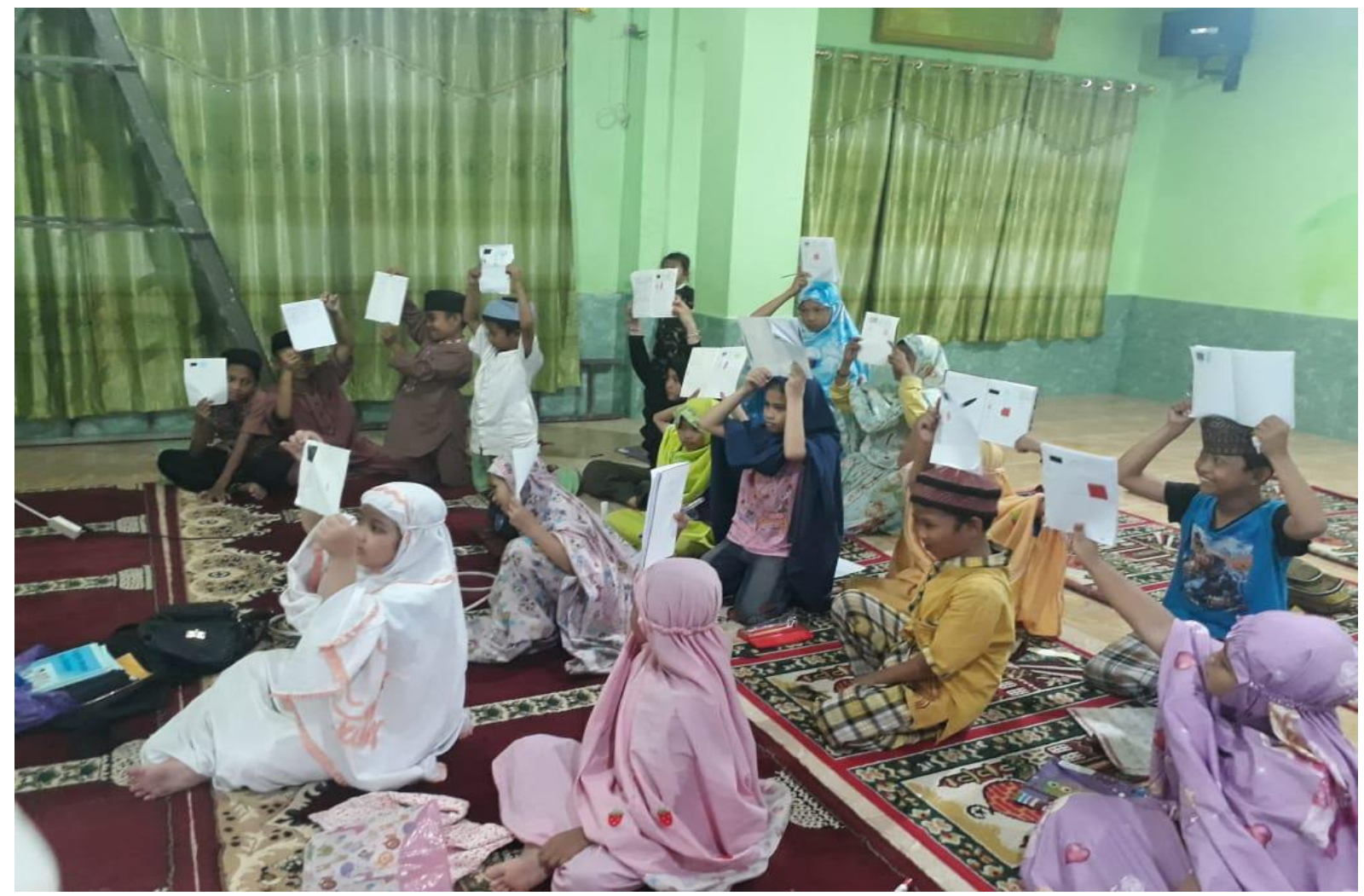

Gambar 4. Materi pembelajaran Shape

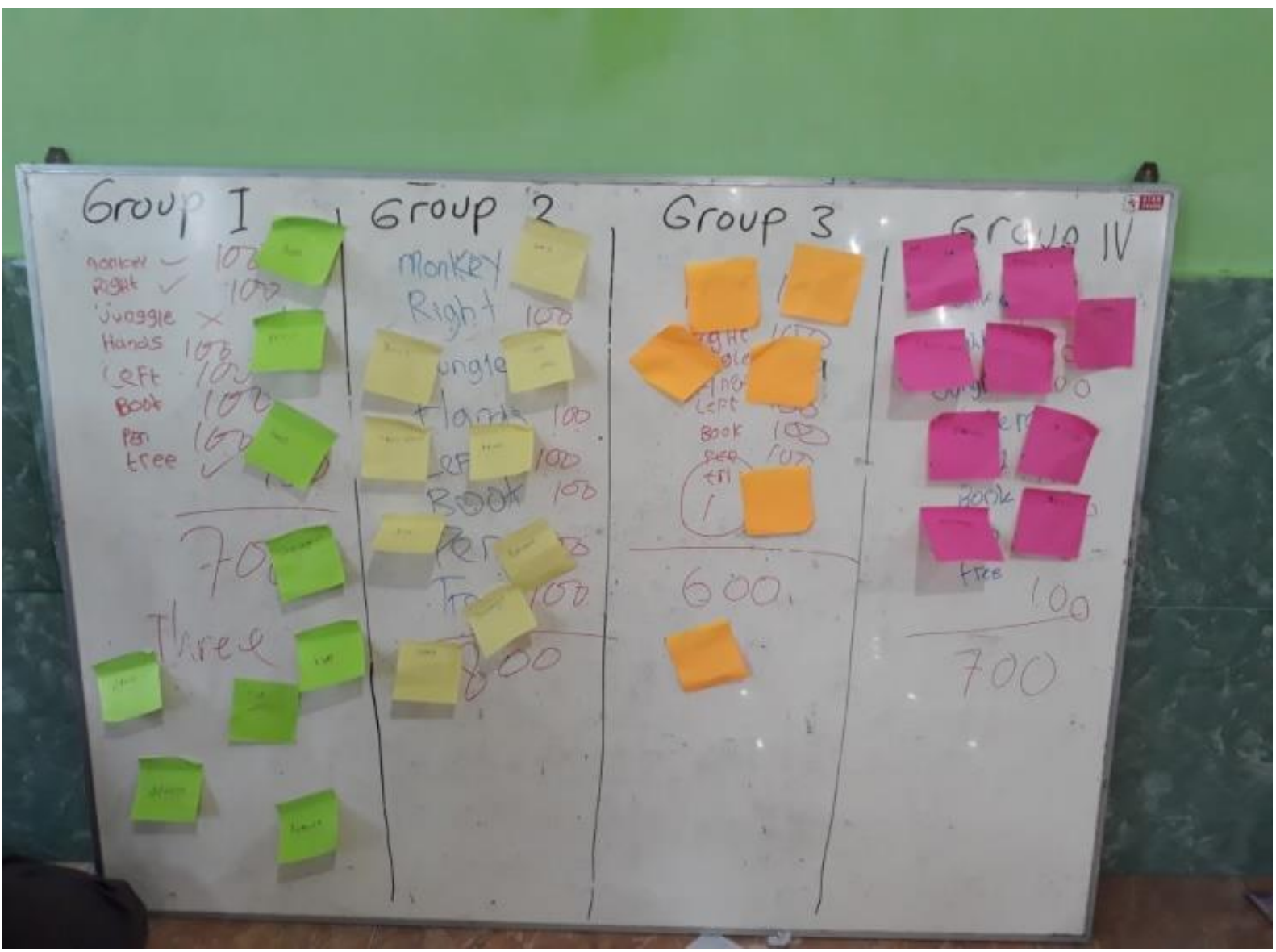

Gambar 5. Materi pembelajaran Noun 


\section{Kesimpulan}

Dari hasil pelaksanaan kegiatan pengabdian kepada masyarakat mengenai pembelajaran bahasa Inggris berbasis lagu dan media audio-visual, maka dapat disimpulkan bahwa lagu adalah satu satu strategi pembelajaran yang sangat cocok dan ampuh dalam mengajarkan bahasa Inggris untuk anak-anak sebagai sumber belajar yang autentik dan dipadukan dengan media audio-visual.

Kegiatan pengabdian semacam ini perlu diprogramkan secara berkelanjutan agar kemampuan Bahasa Inggris siswa terus dilatih dan digunakan. Ini terlihat dari hasil kegiatan belajar siswa yang semakin meningkat di setiap pertemuan.

\section{Ucapan Terimakasih}

Terima kasih kepada Lembaga Pengabdian kepada Masyarakat (LPkM) Universitas Muslim Indonesia Makassar yang telah mendanai kegiatan pengabdian ini. Terima kasih juga kepada Pengurus Taman Pendidikan Alqur'an (TPA) Jannatul Firdaus sebagai mitra kegiatan pengabdian Pembelajaran Bahasa Inggris berbasis lagu dan media audio visual.

\section{Referensi}

BSNP. (2006). Permendiknas RI No. 22 Tahun 2006 tentang Standar Kompetensi Lulusan Pendidikan Dasar dan Menengah. Jakarta: BSNP.

Brewster, J., Ellis, G., \& Girard, D. (2002). The Primary English Teacher's Guide. England: Penguin English

Diknas dan LP2MI Kota Pare-Pare. (2004). Kurikulum Pembelajaran Bahasa Inggris Kelas V dan VI Sekolah Dasar. Pare Pare: Dinas P dan K dengan LP2MI

Ratminingsih, N. M., \& Budasi, I G. (2014). Pengembangan media audio pembelajaran bahasa Inggris berbasis lagu kreasi di kelas lima sekolah dasar. Laporan Penelitian. Universitas Pendidikan Ganesha Singaraja.

Sadiman, A. S., Rahardjo, R., Haryono, A., \& Harjito, H. (2002). Media Pendidikan (Pengertian, Pengembangan dan Pemanfaatannya). Jakarta: Raja Grafindo Persada. 